\title{
Signaling by the TGF $\beta$ Superfamily
}

\section{Jeffrey L. Wrana}

Samuel Lunenfeld Research Institute, Mount Sinai Hospital, Toronto, Ontario M5G 1X5, Canada

Correspondence:wrana@lunenfeld.ca

The transforming growth factor $\beta$ (TGF $\beta$ ) superfamily was discovered in a hunt for autocrine factors secreted from cancer cells that promote transformation (Roberts et al. 1981). However, it soon became clear that TGF $\beta$ and the related bone morphogenetic proteins (BMPs) regulate diverse developmental and homeostatic processes and are mutated in numerous human diseases. Furthermore, TGF $\beta$-superfamily members such as activins, Nodal, and growth differentiation factors (GDFs) were shown to control cell fate as a function of concentration, thus defining them as a key class of secreted morphogens (Green and Smith 1990).

TGF $\beta$-superfamily members are highly conserved across animals and comprise the largest family of secreted morphogens. Ligands are produced by cleavage of a prodomain that releases active disulfide-linked homo- or heterodimers. TGF $\beta$ (plus activin, Nodal, and GDFs) and BMPs both signal through transmembrane serine/threonine kinase receptors. These are typically presented as using distinct downstream pathways (see Figs. 1 and 2), although some crosstalk in certain cell types occurs. In each pathway there are two kinds of receptors: type I and type II (Massague 1998). Ligand binding induces formation of heterotetramers containing two type II and two type I receptors, which allows the constitutively active type II receptor to phosphorylate a glycine-serine (GS)-rich region in the type I receptor. This initiates signaling through the Smad pathway (Fig. 1), with the phosphorylated GS region providing a docking site for receptor-regulated Smad proteins (R-Smads). In TGF $\beta$ signaling, this is promoted by Smad anchor for receptor activation (SARA) in the endosomal compartment (Attisano and Wrana 2002).

Despite the large TGF $\beta$ superfamily $(>30$ members in humans), the receptor repertoire is limited: only five type II and seven type I receptors are encoded in mammalian genomes, with the type I receptors funneling signaling into one of two distinct R-Smad pathways: the TGF $\beta$-Smad pathway (R-Smad2/3) or the BMP-Smad pathway (RSmad1/5/8) (Massague 2012). Docking of R-Smads allows phosphorylation of the last two serines in their carboxyl termini by the type I kinase, which induces dissociation from the receptor, binding to the common Smad, Smad4, and nuclear accumulation of the Smad complex. In the nucleus, most Smads regulate transcriptional responses by direct binding of their MH1 domain to DNA (Smad2 only binds to DNA indirectly) in cooperation with various DNA-binding partners that include sequence-specific transcription factors. These Smad DNA-binding partners typically bind to the R-Smad, thus maintaining specificity of the transcriptional response. Smads also interact with transcriptional coactivators or corepressors that modulate the transcriptional output. Interestingly, the remaining two Smads, Smad6 and Smad7, are transcriptional targets of R-Smads and act in a negative-feedback loop to inhibit signaling by interacting with the receptors and recruiting Smurf and related ubiquitin ligases of the Nedd4 family to induce receptor degradation. SnoN and the related Ski, as well as Arkadia, a ring-finger ubiquitin ligase (also known as RNF111), are important examples of negative and positive regulators of Smad2/3-dependent transcription, respectively (Stroschein et al. 1999; Niederlander et al. 2001). SnoN and Ski negatively regulate the pathway as corepressors of Smads, whereas Arkadia promotes signaling by degrading negative regulators of the pathway, such as Smad7 and SnoN/Ski.

The Smad pathways are the major mediators of transcriptional responses induced by the TGF $\beta$ family, which control cell-fate determination, cell-cycle arrest, apoptosis, and actin rearrangements. However, receptor signaling is not restricted to R-Smad activation (Fig. 2). The type II receptor phosphorylates Par6 polarity proteins bound to the type I receptor to dissolve tight junctions in epithelial cells (Ozdamar et al. 2005) and specify axons (Yi et al. 2010). Furthermore, protein phosphatase 2A (PP2A) is regulated by the receptors (Griswold-Prenner et al. 1998), signaling via SHC-Grb2 has been reported (Lee et al. 2007), and interactions between the kinase PAK and the TGF $\beta$ receptor link it to cytoskeletal and focal adhesion dynamics

Editors: Lewis Cantley, Tony Hunter, Richard Sever, and Jeremy Thorner

Additional Perspectives on Signal Transduction available at www.cshperspectives.org

Copyright $\odot 2013$ Cold Spring Harbor Laboratory Press; all rights reserved; doi: 10.1101/cshperspect.a011197 


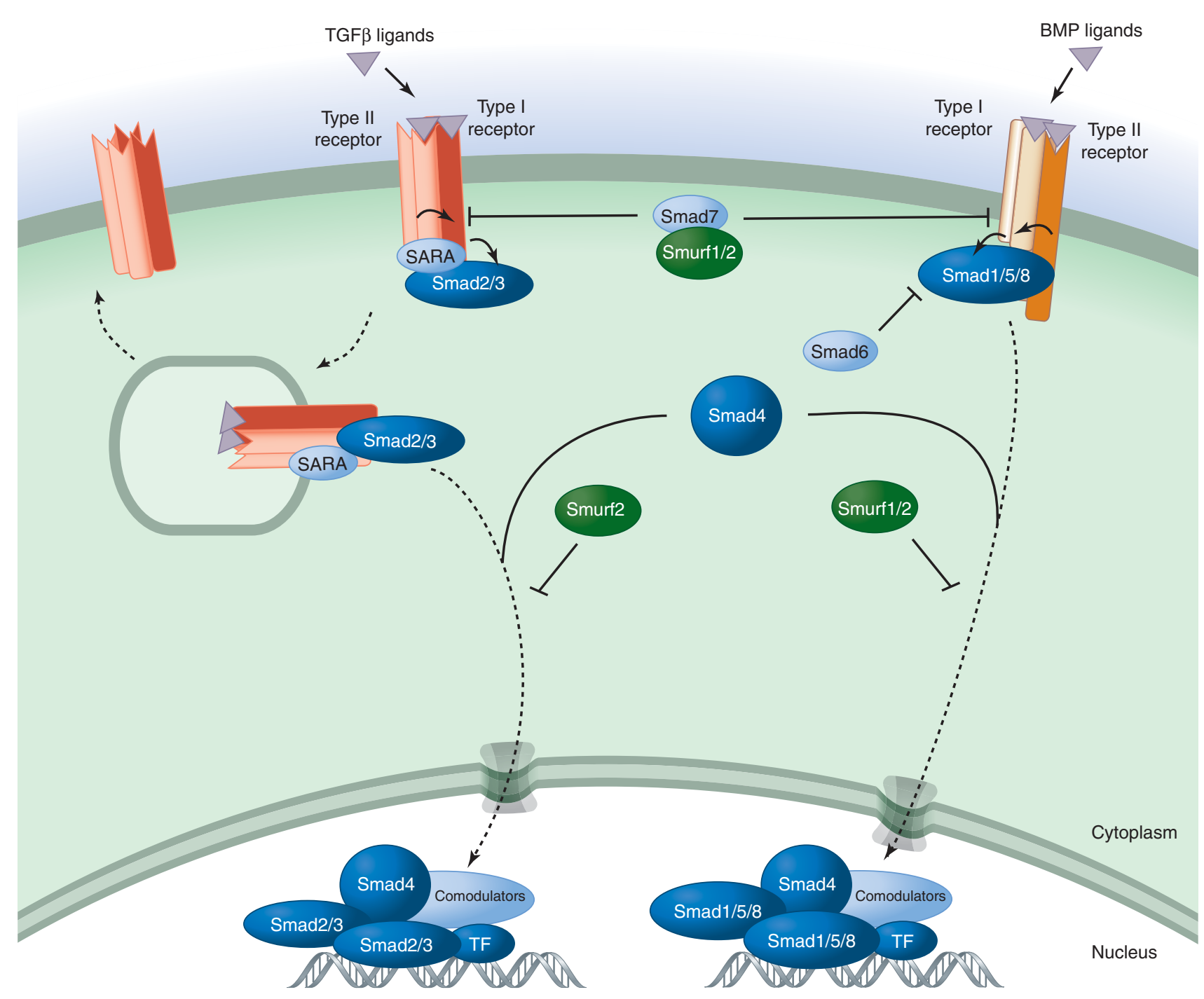

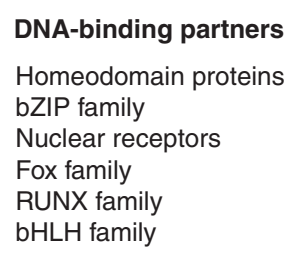

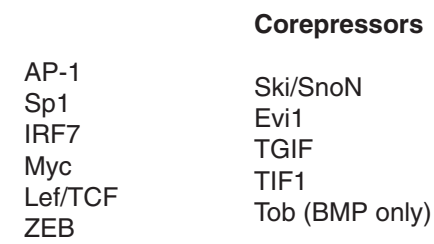

Figure 1. Smad signaling.
(Wilkes et al. 2009). BMPRII is of particular interest because it has a unique carboxy-terminal tail that serves as a docking site for binding of the kinases LIMK and JNK, thus linking BMP signaling to the actin cytoskeleton and the microtubule network, respectively (Miyazono et al. 2010; Podkowa et al. 2010). These pathways are critical in neuronal dendritogenesis and may be important in familial pulmonary hypertension, in which mutations in BMPRII are a major cause of disease (Morrell 2011). Numerous kinase cascades, including the ERK, JNK, and p38 MAPK path- ways, are also regulated by TGF $\beta$ signaling (Mu et al. 2012), with signaling to TRAF6 being one important mechanism of MAPK regulation. These non-Smad pathways combine with the gene-expression programs controlled by Smads to yield an integrated response to TGF $\beta$ signals.

Finally, TGF $\beta$ signaling is embedded in a higher-order network of interactions with other signaling pathways. For example, Smads interact with the Wnt pathway (via Lef/ TCF transcription factors and $\beta$-catenin), the Hedgehog pathway (via Gli transcriptional regulators), and the Hippo 


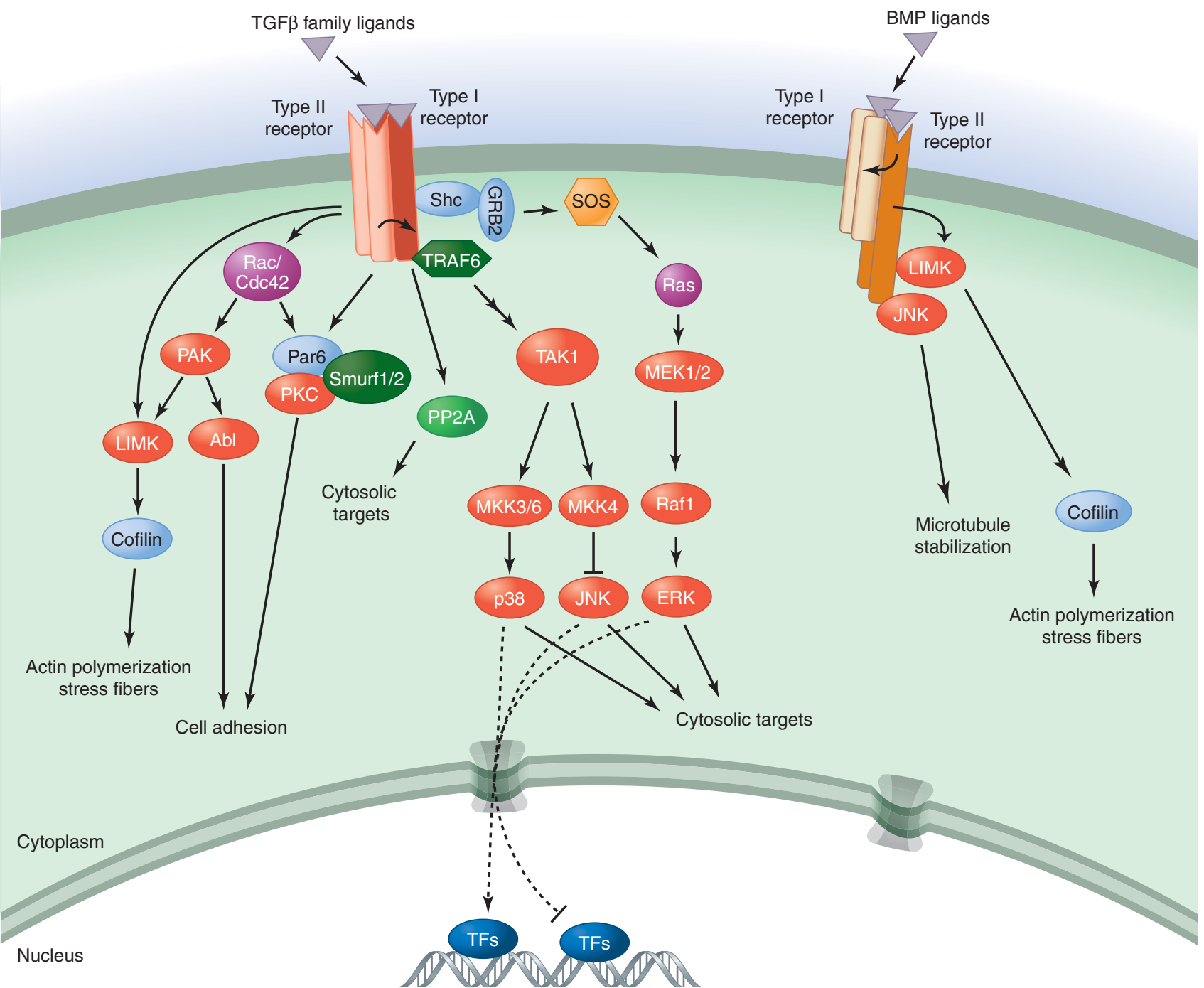

Figure 2. Non-Smad signals.

pathway (via TAZ and YAP). This provides an integrated signaling network that allows contextual interpretation of morphogen signals in diverse biological settings (Attisano and Wrana 2013).

\section{REFERENCES}

Attisano L, Wrana JL. 2002. Signal transduction by the TGF- $\beta$ superfamily. Science 296: 1646-1647.

Attisano L, Wrana JL. 2013. Signal integration in TGF- $\beta$, WNT and Hippo pathways. F1000Prime Rep 5: 17.

Green JB, Smith JC. 1990. Graded changes in dose of a Xenopus activin A homologue elicit stepwise transitions in embryonic cell fate. Nature 347: 391-394.

Griswold-Prenner I, Kamibayashi C, Maruoka EM, Mumby MC, Derynck R. 1998. Physical and functional interactions between type I transforming growth factor $\beta$ receptors and $\mathrm{B} \alpha$, a WD- 40 repeat subunit of phosphatase 2A. Mol Cell Biol 18: 6595-6604.

Lee MK, Pardoux C, Hall MC, Lee PS, Warburton D, Qing J, Smith SM, Derynck R. 2007. TGF- $\beta$ activates Erk MAP kinase signalling through direct phosphorylation of ShcA. EMBO J 26: 3957-3967.
Massague J. 1998. TGF- $\beta$ signal transduction. Annu Rev Biochem 67: $753-791$.

Massague J. 2012. TGFß signalling in context. Nat Rev Mol Cell Biol 13: $616-630$.

Miyazono K, Kamiya Y, Morikawa M. 2010. Bone morphogenetic protein receptors and signal transduction. J Biochem 147: 35-51.

Morrell NW. 2011. Role of bone morphogenetic protein receptors in the development of pulmonary arterial hypertension. Adv Exp Med Biol 661: 251-264.

Mu Y, Gudey SK, Landström M. 2012. Non-Smad signaling pathways. Cell Tissue Res 347: 11-20.

Niederlander C, Walsh JJ, Episkopou V, Jones CM. 2001. Arkadia enhances nodal-related signalling to induce mesendoderm. Nature 410: $830-834$.

Ozdamar B, Bose R, Barrios-Rodiles M, Wang HR, Zhang Y, Wrana JL. 2005. Regulation of the polarity protein Par6 by TGF$\beta$ receptors controls epithelial cell plasticity. Science 307: 16031609.

Podkowa M, Zhao X, Chow CW, Coffey ET, Davis RJ, Attisano L. 2010. Microtubule stabilization by bone morphogenetic protein receptormediated scaffolding of c-Jun $\mathrm{N}$-terminal kinase promotes dendrite formation. Mol Cell Biol 30: 2241-2250. 


\section{J.L. Wrana}

Roberts AB, Anzano MA, Lamb LC, Smith JM, Sporn MB. 1981. New class of transforming growth factors potentiated by epidermal growth factor: Isolation from non-neoplastic tissues. Proc Natl Acad Sci 78: 5339-5343.

Stroschein SL, Wang W, Zhou S, Zhou Q, Luo K. 1999. Negative feedback regulation of TGF- $\beta$ signaling by the SnoN oncoprotein. Science 286: $771-774$.
Wilkes MC, Repellin CE, Hong M, Bracamonte M, Penheiter SG, Borg JP, Leof EB. 2009. Erbin and the NF2 tumor suppressor Merlin cooperatively regulate cell-type-specific activation of PAK2 by TGF- $\beta$. Dev Cell 16: 433-444.

Yi JJ, Barnes AP, Hand R, Polleux F, Ehlers MD. 2010. TGF- $\beta$ signaling specifies axons during brain development. Cell 142: 144157. 


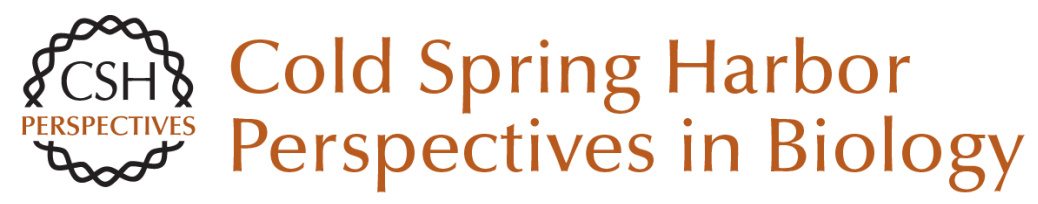

\section{Signaling by the TGF $\beta$ Superfamily}

Jeffrey L. Wrana

Cold Spring Harb Perspect Biol 2013; doi: 10.1101/cshperspect.a011197

Subject Collection Signal Transduction

Cell Signaling and Stress Responses Gökhan S. Hotamisligil and Roger J. Davis

Protein Regulation in Signal Transduction Michael J. Lee and Michael B. Yaffe

Synaptic Signaling in Learning and Memory Mary B. Kennedy

Vertebrate Reproduction Sally Kornbluth and Rafael Fissore

Signaling in Lymphocyte Activation Doreen Cantrell

Signaling in Muscle Contraction Ivana Y. Kuo and Barbara E. Ehrlich

Toll-Like Receptor Signaling Kian-Huat Lim and Louis M. Staudt

Signaling Pathways that Regulate Cell Division Nicholas Rhind and Paul Russell
Second Messengers

Alexandra C. Newton, Martin D. Bootman and John D. Scott

\section{Signals and Receptors} Carl-Henrik Heldin, Benson Lu, Ron Evans, et al.

Cell Death Signaling Douglas R. Green and Fabien Llambi

Signaling Networks that Regulate Cell Migration Peter Devreotes and Alan Rick Horwitz

Signaling Networks: Information Flow, Computation, and Decision Making Evren U. Azeloglu and Ravi lyengar

Signal Transduction: From the Atomic Age to the Post-Genomic Era Jeremy Thorner, Tony Hunter, Lewis C. Cantley, et al.

Signaling by the TGF $\beta$ Superfamily Jeffrey L. Wrana

Subversion of Cell Signaling by Pathogens Neal M. Alto and Kim Orth

For additional articles in this collection, see http://cshperspectives.cshlp.org/cgi/collection/

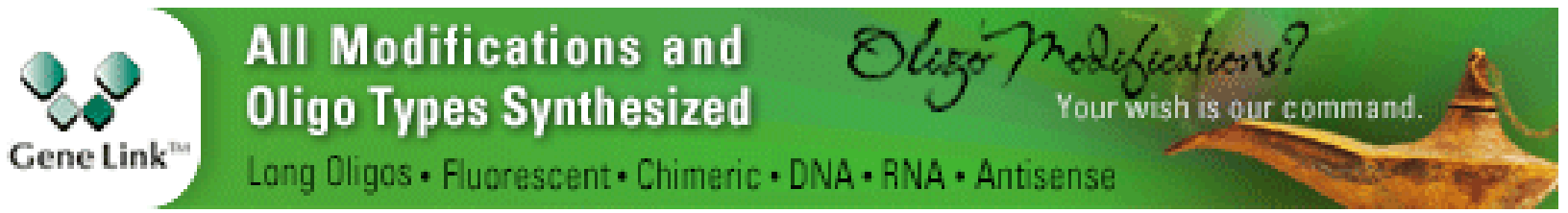

Copyright @ 2013 Cold Spring Harbor Laboratory Press; all rights reserved 